\title{
A Rare Complication of Cryotherapy Used in Endobronchial Malignant Melanoma: "Cryoshock"
}

\author{
Endobronşiyal Malign Melanomda Kullanılan Kriyoterapinin Nadir Bir \\ Komplikasyonu: "Kriyoşok"
}

Ayse Bahadir', Mediha Gonenc Ortakoylu', Isil Kibar², Sinem lliaz³, Mehmet Akif Ozgul', Erdogan Cetinkaya', Naciye Arda ${ }^{4}$

\begin{abstract}
Endobronchial metastases (EBMs) of malignant melanoma are rare. Cryotherapy is a safe and widely used method for the treatment of EBMs. Herein, we present a malignant melanoma case with EBMs treated with cryotherapy and discuss in the light of the literature data. A 56-year-old male patient was hospitalized for the evaluation of a lung mass. Thoracic computed tomography scan showed a $3 \times 4 \times 7 \mathrm{~cm}$ necrotic central mass lesion narrowing the left main bronchus. We performed rigid bronchoscopy and applied mechanical resection and cryotherapy. Biopsies revealed malignant melanoma metastases. Three days after the procedure, he was admitted to the hospital with signs of possible cryoshock. To the best of our knowledge, there is no paper reporting cryoshock as a complication of cryotherapy application in lung malignancies in the literature.
\end{abstract}

Key words: Cryotherapy, shock, malignant melanoma, endobronchial, metastasis.

\section{Özet}

Malign melanomun endobronşiyal metastazı (EBM) nadir olarak bildirilmiştir. Kriyoterapi EBM tedavisinde yaygın olarak ve güvenle kullanılmaktadır. Kriyoterapi ile tedavi edilmiş malign melanoma bağlı bir EMB olgusunu sunmak ve ilgili literatür ile tartışmayı amaçladık. Elli altı yaşında erkek hasta, bir akciğer kitlesinin değerlendirmesi için yatırıldı. Toraks BT'de sol ana bronşu daraltan $3 \times 4 \times 7 \mathrm{~cm}$ nekrotik santral bir kitle görüldü. Riiid bronkoskopi yapıldı ve mekanik rezeksiyon ve kriyoterapi uygulandı. Biyopsiler malign melanomun metastazı olarak sonuçlandı. İşlemden üç gün sonra muhtemel kriyoşok bulgularıla hastaneye başvurdu. Bildiğimiz kadarı ile literatürde akciğer malignitelerinde kriyoterapi kullanımının komplikasyonu olarak kriyoşoku bildiren bir yazı bulunmamaktadır.

Anahtar Sözcükler: Kriyoterapi, şok, malign melanom, endobronşiyal, metastaz.

\footnotetext{
'Department of Pulmonology, Yedikule Education and Research 'Yedikule Göğüs Hastalıkları ve Göğüs Cerrahisi Eğitim ve Hospital for Chest Diseases and Thoracic Surgery, İstanbul, Turkey ${ }^{2}$ Department of Pulmonology, Esenyurt State Hospital, İstanbul, Turkey

${ }^{3}$ Department of Pulmonology, Koç University Hospital, İstanbul, Turkey

${ }^{4}$ Department of Pathology, Yedikule Education and Research Hospital for Chest Diseases and Thoracic Surgery, İstanbul, Turkey Arasstırma Hastanesi, Göğüs Hastalıkları Bölümü, İstanbul ${ }^{2}$ Esenyurt Devlet Hastanesi, Göğüs Hastalıkları Bölümü, İstanbul

${ }^{3}$ Koç Üniversitesi Hastanesi, Göğüs Hastalıkları Bölümü, İstanbul

${ }^{4}$ Yedikule Göğüs Hastalıkları ve Göğüs Cerrahisi Eğitim ve Araştırma Hastanesi, Patoloji Bölümü, İstanbul
}

Submitted (Başvuru tarihi): 03.07.2015 Accepted (Kabul tarihi): 14.09.2015

Correspondence (iletişim): Sinem lliaz, Department of Pulmonology, Koç University Hospital, İstanbul, Turkey

e-mail:snmkaraosman@gmail.com 
Endobronchial metastases (EBMs) of extrapulmonary malignancies are extremely rare with an estimated prevalence of 2 to $50 \%$. The most common malignancies causing EBMs are breast, kidney, and colon carcinomas. Endobronchial spread of malignant melanoma cases have been also reported rarely $(1,3)$. Cryotherapy is a safe and widely used method for the treatment of EBMs (2). Herein, we present a malignant melanoma case with EBMs treated with cryotherapy.

\section{CASE}

A 56-year-old male patient was hospitalized in another center with the symptoms of cough, shortness of breath, and weight loss. His chest $X$-ray revealed opacity in the left hilar region, which was later confirmed by thoracic computed tomography (CT). Thoracic CT scan showed a $3 \times 4 \times 7 \mathrm{~cm}$ necrotic mass lesion extending from the left subcarinal area to the periaortic area and narrowing the left main bronchus (Figures 1 and 2). He was referred to our hospital for the further evaluation and treatment. In his medical history, he had a 2-cm ulcerated pigmented nodular lesion on his left gluteal area three years ago. The histopathological examination result was reported as a nodular malignant melanoma. The patient underwent positron emission tomography-CT (PET-CT) three years ago and showed no pathological F-18 fluorodeoxyglucose (FDG) uptake. Then, the patient refused further examination and the treatment. In his current admission to our hospital, laboratory test results were as follows: leukocyte: 9,700/ $\mathrm{mm}^{3}$, hematocrit: 41\%, hemoglobin: $15 \mathrm{~g} / \mathrm{dl}$, platelets: $176,000 / \mathrm{mm}^{3}$, erythrocyte sedimentation rate: $30 \mathrm{~mm} /$ hour with normal biochemical parameters. Due to the suspected EBM on thoracic CT, we performed fiberoptic bronchoscopy (FOB). We observed a vegetative necrotic mass almost completely obstructing the distal left main bronchus (Figure 3). As the biopsy specimens taken during the FOB did not establish a definite diagnosis, we performed rigid bronchoscopy to confirm the diagnosis and treat the mass simultaneously. We applied mechanical resection and cryotherapy via nitrous oxide for three times each for 30 to 60 seconds. After the procedure, the left main bronchus was patent completely. We did not observe any complication during the followup and the patient was discharged the same day. Histopathological examination result was reported as malignant melanoma metastases (Figure 4).

Three days after bronchoscopy, the patient was admitted to the hospital with complaints of cough, shortness of breath, wheezing, fatigue, nausea, loss of appetite, sweating, and dizziness. On his physical examination, there were fine crackles on basal areas of the lungs bilaterally. Hepatosplenomegaly and bilateral axillary lymphadenopathy were also present. His blood pressure was 90/60 $\mathrm{mmHg}$, pulse rate was 100 bpm and rhythmic. Arterial blood gas analysis on ambient air revealed $\mathrm{pH}$ : 7.46, $\mathrm{PaCO}_{2}: 24.6 \mathrm{mmHg}, \mathrm{PaO}_{2}: 52.8 \mathrm{mmHg}, \mathrm{SaO}_{2}$ : 89\%, $\mathrm{HCO}_{3}: 20.2 \mathrm{mEq} / \mathrm{L}$. Other laboratory results were as follows: leukocytes: $55,000 / \mathrm{mm}^{3}$, hematocrit: $27.6 \%$, hemoglobin: $9.5 \mathrm{~g} / \mathrm{dl}$, platelets: $36,000 / \mathrm{mm}^{3}$, creatine: $0.98 \mathrm{mg} / \mathrm{dL}, \quad \mathrm{C}$-reactive protein (CRP): $81 \mathrm{mg} / \mathrm{L}$, AST: $76 \mathrm{U} / \mathrm{L}, \mathrm{ALT}: 38 \mathrm{U} / \mathrm{L}$, calcium: $8.9 \mathrm{mg} / \mathrm{dL}$. He was transferred to the intensive care unit (ICU) with the diagnosis of acute respiratory failure and he died on the third day of ICU admission.

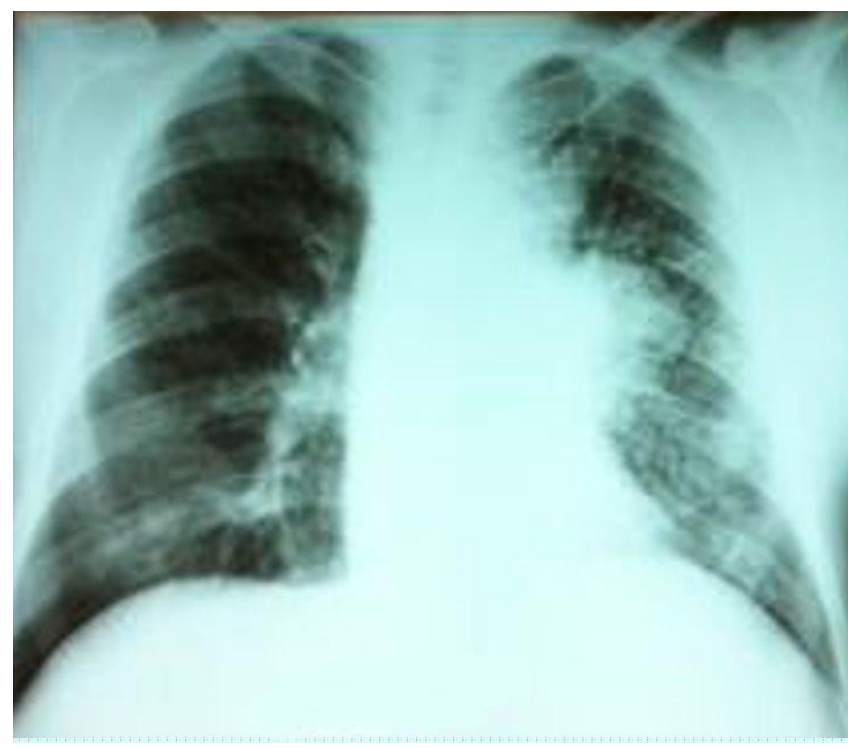

Figure 1: Chest $X$-ray showing left hilar opacity

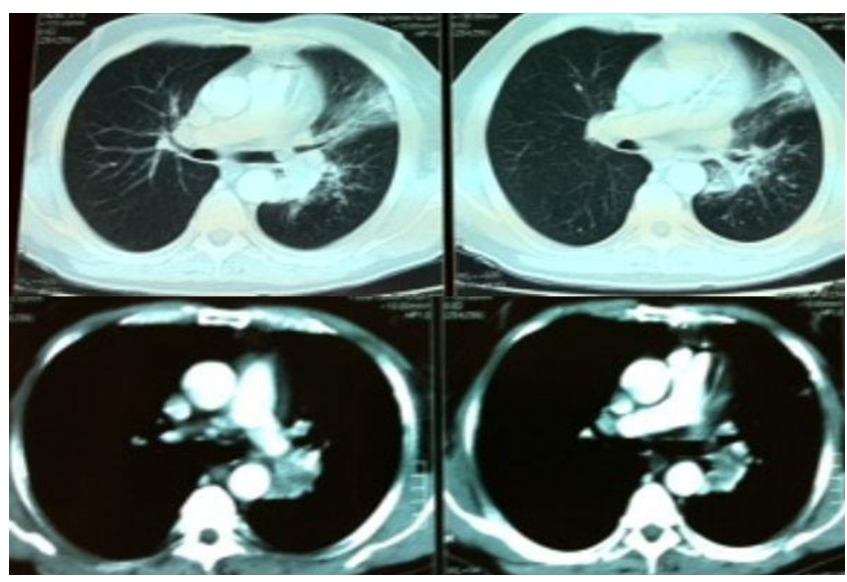

Figure 2: Thoracic CT showing a $3 \times 4 \times 7 \mathrm{~cm}$ necrotic mass lesion extending from left subcarinal area to the periaortic area and narrowing left main bronchus 


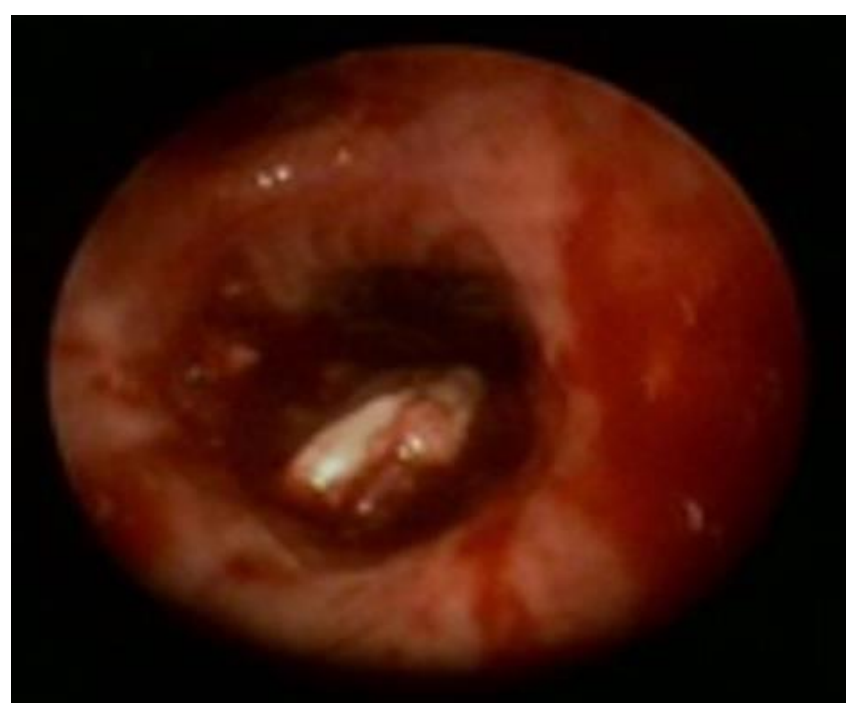

Figure 3: A bronchoscopic image showing a necrotic solid mass lesion obstructing the enterance of distal left main bronchus

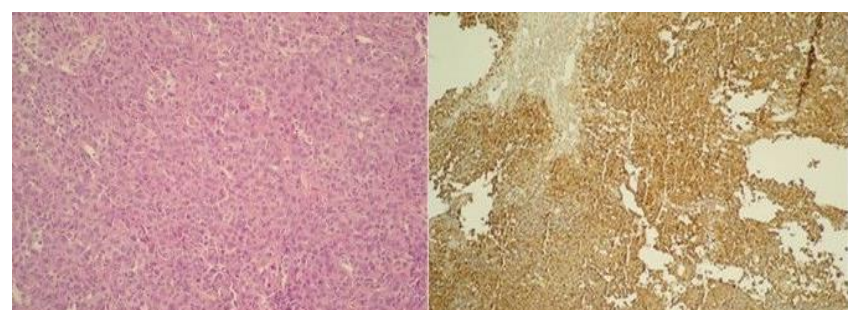

Figure 4: A pathology image of the tumor consisted of big epitheloid cells forming solid compact layers, x200 H\&E (left image) and S-100 positivity can be seen in the specimen by immunohistochemical staining, x200 S-100 (right image)

\section{DISCUSSION}

Lung metastasis due to a malignant melanoma consists of 5 to $15 \%$ of all lung metastases. Its radiology differs as follows: solitary, multiple, or miliary pulmonary nodules, lymphangitic infiltration/invasion, hilar/mediastinal lymphadenopathy, atelectasis secondary to bronchial obstruction, pleural effusion or costal destruction (2). According to the literature, good prognostic factors associated with malignant melanoma were diagnosis under 65 years of age, female sex, localization in the extremities, the absence of lymph node involvement or distant metastases, and normal LDH levels (4). Akoglu et al. (5) reported the duration of metastasis development after the diagnosis of malignant melanoma as 36 months. Similarly, our patient had pulmonary metastases three years after the diagnosis of the malignant nodule in the left gluteal region and he did not receive any treatment for the disease in this period. In the literature, the mean survival after the onset of radiological signs of lung metastasis of malignant melanoma was seven months (2).

Treatment modalities of EBM can be listed as mechanical debulking, Neodymium-Doped Yttrium-Aluminum-Garnet (Nd-YAG) laser, electrocautery, argon plasma coagula- tion, cryotherapy, brachytherapy, and stent placement. Among these, cryotherapy is defined as repetitive freeze/thaw cycles resulting in tissue damage and destruction. In this method, the cell damage has two mechanisms: First, rapid-freezing causes the death of cells by forming ice crystals. Second, re-circulation begins in the frozen tissue after melting. However, there is a progressive deterioration in the microcirculation due to microthrombosis and endothelial cell damage. Tissue destruction occurs by the cessation of circulation. Nitrous oxide or liquid nitrogen is usually used to form a temperature of $-80^{\circ} \mathrm{C}$. The major advantage is the lack of perforation risk due to the cartilage and fibrous tissue being resistant to cryotherapy. In addition, less bleeding is seen with its hemostasis effect. The disadvantages of cryotherapy procedure can be listed as longer duration of treatment and the need for re-bronchoscopy. About two to four days after cryotherapy, bronchoscopy needs to be repeated to clean the necrotic debris. As we performed mechanical debulking and maintained complete bronchial clearance/patency in our case, we did not repeat the procedure. Cryotherapy can be used safely with rigid bronchoscopy, as well as with FOB (6).

Cryotherapy has been widely used in the treatment of hepatic tumors. It leads to nuclear factor-kb activation in the liver after 30 minutes, and in lung and kidney after one hour. In addition, it has been reported that TNFalpha, macrophage, and interferon level significantly increase. Also, serum thromboxane level increases to nine fold after 30 minutes and it returns to normal levels 24 hours after the procedure. Secreted cytokines lead to an increased pulmonary lymph-plasma protein clearance and pulmonary arterial pressure. It has been reported that lymph-plasma clearance continues to increase, even if pulmonary arterial pressure normalizes. Accordingly, changes in capillary permeability, parenchymal hemorrhage, and alveolar edema may occur. In the literature, a clinical presentation consisted of thrombocytopenia, disseminated intravascular coagulation, renal/hepatic failure and acute respiratory distress syndrome is defined as cyroshock (7).

In the present case, we interpreted the clinical presentation occurred three days after the endobronchial therapy as cryoshock. The findings such as hypotension, thrombocytopenia, reduced hematocrit and hemoglobin levels, new-onset hypoxia resistant to the oxygen therapy were consistent with the development of increased capillary permeability, parenchymal hemorrhage, and alveolar edema. New-onset leukocytosis, bilateral axillary lym- 
phadenopathy, and hepatosplenomegaly, increased aspartate aminotransferase (AST) levels, treatment-resistant hypotension and poor overall status also supported cryoshock. However, the clinical presentation has also some similarities with sepsis and septic shock. Sepsis is a clinical syndrome which is complicated with an infection. It is defined with fever or hypothermia, tachycardia, tachypnea, leukocytosis or leukopenia, and infection. If there is also hypotension resistant to adequate volume replacement, it is called septic shock $(8,9)$. There may be multiorgan dysfunction in both cryoshock and septic shock. The main difference between cryoshock and sepsis/septic shock is not having any clue for an infection in cryoshock. However, in some cases, it can be impossible to differentiate these clinical syndromes from each other. In our case, there was no fever or any sign of an infectious cause. The exact cause of the death was not determined, as no autopsy study was performed. Therefore, our interpretation may be speculative. To the best of our knowledge, there is no article reporting cryoshock as a complication of cryotherapy application in lung malignancies in the literature.

In conclusion, we present a rare case with EBMs of malignant melanoma and possibly complicated with cryoshock after cryotherapy of EBM. To the best of our knowledge, this is the first case in the English literature having cryoshock after cryotherapy for EBM due to malignant melanoma. However, further studies are required to establish a definite conclusion on the possibility of lung malignancies-induced cryoschock.

\section{CONFLICTS OF INTEREST}

None declared.

\section{AUTHOR CONTRIBUTIONS}

Concept - A.B., M.G.O., I.K., S.I., M.A.O., E.C., N.A.; Planning and Design - A.B., M.G.O., I.K., S.I., M.A.O., E.C., N.A.; Supervision - A.B., M.G.O., I.K., S.I., M.A.O., E.C., N.A.; Funding -; Materials -; Data Collection and/or Processing - A.B., I.K., M.G.O.; Analysis and/or Interpretation - A.B.; Literature Review - A.B., M.G.O.; Writing - A.B., S.I.; Critical Review - E.C., M.G.O., S.I., N.A., I.K.

\section{YAZAR KATKILARI}

Fikir - A.B., M.G.O., I.K., S.I., M.A.O., E.C., N.A.; Tasarım ve Dizayn - A.B., M.G.O., I.K., S.I., M.A.O., E.C., N.A.; Denetleme - A.B., M.G.O., I.K., S.I., M.A.O., E.C., N.A.; Kaynaklar -; Malzemeler -; Veri Toplama ve/veya İşleme - A.B., I.K., M.G.O.; Analiz ve/veya Yorum - A.B.; Literatür Taraması - A.B., M.G.O.; Yazıyı Yazan - A.B., S.I.; Eleştirel İnceleme - E.C., M.G.O., S.I., N.A., I.K.

\section{REFERENCES}

1. Kiryu T, Hoshi $H$, Matsui E, Iwata H, Kokubo M, Shimokawa K, et al. Endotracheal/endobronchial metastases: clinicopathologic study with special reference to developmental modes. Chest 2001; 119:768-75. [CrossRef]

2. Webb WR, Gamsu G. Thoracic metastasis in malignant melanoma. A radiographic survey of 65 patients. Chest $1977 ; 71: 176-81$.

3. Bolliger CT, Mathur PN, Beamis JF, Becker HD, Cavaliere $\mathrm{S}$, Colt $\mathrm{H}$, et al (European Respiratory Society/American Thoracic Society). ERS/ATS statement on interventional pulmonology. European Respiratory Society/ American Thoracic Society. Eur Respir J 2002; 19:35673.

4. Homsi J, Kashani-Sabet M, Messina JL, Daud A. Cutaneous melanoma: prognostic factors. Cancer Control 2005; 12:223-9.

5. Akoglu S, Ucan ES, Celik G, Sener G, Sevinc C, Kılınc O et al. Endobronchial metastases from extrathoracic malignancies. Clin Exp Metastasis 2005; 22:587-91. [CrossRef]

6. Ernst A, Feller-Kopman D, Becker HD, Mehta AC. Central airway obstruction. Am J Respir Crit Care 2004; 169:1278-97. [CrossRef]

7. Gravante G, Sconocchia G, Ong SL, Dennison AR, Lloyd DM. Immunoregulatory effects of liver ablation therapies for the treatment of primary and metastatic liver malignancies. Liver Int 2009; 29:18-24. [CrossRef]

8. Gustot T. Multiple organ failure in sepsis: prognosis and role of systemic inflammatory response. Curr Opin Crit Care 2011 ; 17:153-9. [CrossRef]

9. Bone RC, Balk RA, Cerra FB, Dellinger RP, Fein AM, Knaus WA, et al. Definitions for sepsis and organ failure and guidelines for the use of innovative therapies in sepsis. The ACCP/SCCM Consensus Conference Committee. American College of Chest Physicians/Society of Critical Care Medicine. 1992. Chest 2009; 136(5 Suppl):e28. 